\title{
Evaluating Challenges Facing Global Quick Service Restaurants and Proposed Solutions
}

Mohamed Abdelgawwad Aly Abdelgawwad

University of Sadat City

\section{Abstract}

The global Quick Service Restaurants (QSRs) adapted strategy of "think globally or plan globally and act locally" to accomplish a unique brand name globally. This strategy means to follow the global standards in product (features, quality, quantity, flavor and packaging), design, equipment; service etc. worldwide. Applying this strategy, global QSRs face some economic challenges in achieving standardized products to maintain its brand name in Arab market (Egypt). This study is focusing on evaluating challenges facing the global QSRs and proposed solutions to lure Foreign Capital Investment (FCI) in Egypt especially in the global business (QSRs).

Qualitative research approach adopted in this research because of the globalization phenomenon (Yin, 2009). Research used case study the global QSRs semi-structured interviews with global QSRs managers and experts and printed documents are used. The sampling frame of the global QSRs are McDonald's, KFC, Hardee's and Burger King in Cairo.

Findings that there are some challenges faced the global QSRs in the Arab market (Egypt). These challenges are sourcing raw materials, currency exchange rate, global economic crises, inflation and global food crises. There are some proposed solutions, which are localization strategy, hedging strategy, launching economic meals and sandwich, company share inflation with suppliers and change source of food.

Keywords: Global QSRs, Raw Materials, Currency Exchange Rate, Global Economic Crises, Inflation. Recession, Global Food Crises.

\section{Introduction}

Global QSRs have been vanguard of globalization phenomenon in Arab market. There are various challenges have forced global QSRs to apply "Think globally and acting locally or Plan globally and acting locally" (Viginali, 2001; Brown, 2006) in the Arab market. These challenges prevent global QSRs to launch standardized products out home borders. These challenges are sourcing raw materials in consistent quality, currency exchange rate, global economic crises, inflation and finally recession. Global QSRs depends on global standardisation for the following reasons: cost reduction; enhanced consistent quality for global products; better quality for customer preference; maintain its competitive advantages and attracting customers.

Figure 1: Think or plan globally and acting locally strategy

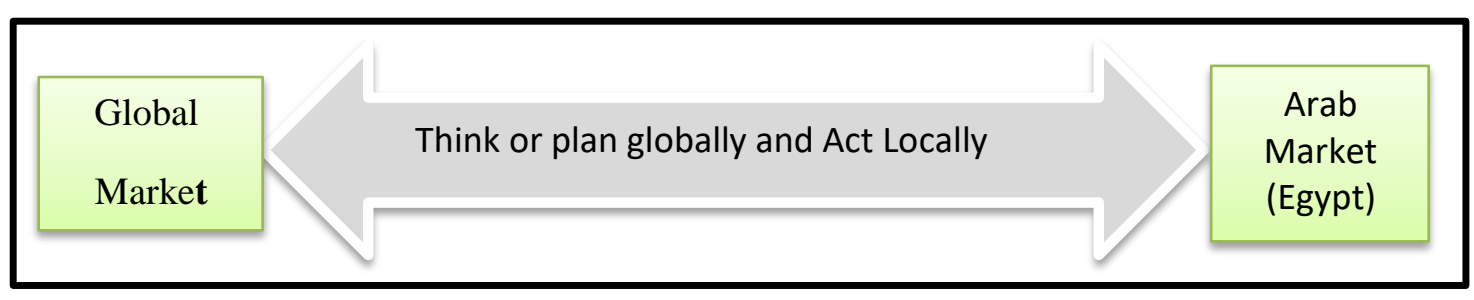

The main aim of this study is to explore the challenges facing global QSRs in the Egypt and how global QSRs overcome these challenges through: 1) undertake critically literature review regarding the strategies of global QSRs planning to operate in Arabian countries aiming to develop conceptual framework to identify challenges which facing global brands and proposed solutions; 2) investigate different perspectives of global QSRs managers and experts in terms of challenges facing 
global QSRs and identify the responses of global QSRs mangers as a reaction to challenges; 3) Examine strategies of the global QSRs as response to economic challenges; 4) Establish a conclusion and a set of recommendations for global QSRs to overcome challenges.

Ball and Roberts (2003: 31) define a restaurant as "an establishment where the public can obtain refreshments or meals, usually for money". However, there are many diverse operations which would be included in this definition, for example pubs (especially gastropubs), bistros, snack bars, cafés, specialty restaurants (such as wokto-walk in the UK), popular restaurants and some fish and chip cafés (Jones, 1996).

"QSRs operations are now more global than ever and international fast food eating continues to increase in popularity" (Kara et al., 1997: 318). The QSR industry is one of the most competitive and saturated business sectors in the USA (Apte and Reyonolds, 1995): "Some of the most successful and largest restaurants chains are part of the quick-service restaurants (QSRs) segment, such as McDonald's, Pizza Hut, Subway and KFC" (Ottenbacher and Harrington, 2009: 524). The most obvious of the quick service restaurants' characteristics are limited menu, limited service and finally standardization as shown in figure no. 2 (Abdelgawwad, 2012).

Figure 2: The Quick Service Restaurants' Characteristics

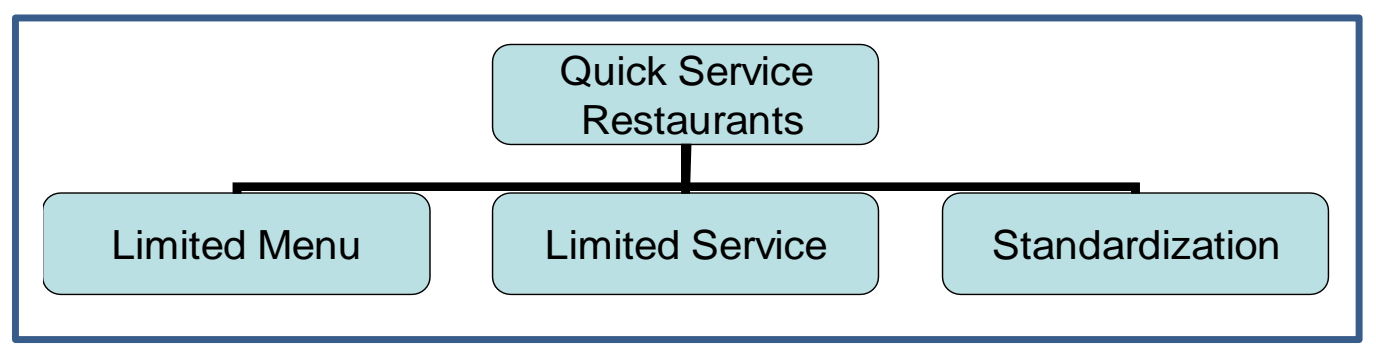

\section{Literature review}

Economic changes contain a wide range of issues, which affected positively or negatively on business in all sectors of global QSRs, e.g. tax regime, inflation, exchanges rate etc. Katsikes et al (2006:808) describes the importance of economic factors for the consumer products: "the economic environment of a host market affects market potential and demand for industrial and consumer products". Economic factors are important for QSRs both in terms of the operational costs of business and in terms of the levels of disposal income available to potential customers (Clarke and Chen, 2007). Issues e.g. income levels and patterns of income distribution, impact on the demand for particular products: "changes in income level and credit availability can affect supply and demand of new products" (Morgan, 2011: online). As Kotler and Armstrong (2010: 103) asserted that "the economic environment consists of factors that affect consumer purchasing power and sending patterns. Marketers must pay close attention to major trends and consumer spending patterns both across and within their world markets".

The price of a product and therefore its attractiveness to potential customers is affected by a number of factors not least the price of raw materials. Fluctuations in the price of raw materials are vital factors that affect the price of new products. Price depends on the quantity sold, so there is an inverse relationship between the price of a new product and the quantity that consumers are willing to buy. High prices lead to customer dissatisfaction, so that demand for a product will decline, and in turn, production will be decreased. In contrast, the lower the price of a new product the more it will be in demand since customers will feel they are getting good value for money (Morgan, 2011). Alongside this, the price of substitute products also affects 
the demand for products (Southland, 2010) so that if a customer can purchase an equivalent product from a competitor at a lower price then she is likely to do so. "Supply and demand of raw materials is the key to new product value. So the less availability of a new product's raw materials leads to increased new product price" (Morgan, 2011:1).

Supply chain management is "the management is upstream and down stream relationships with suppliers and customers in order to deliver superior customer value at less cost to the supply chain as a whole" (Christopher, 2016: 55). Supply chain management plays an important part in supplying global companies with raw materials and manufactured products at stable prices. Significant supply chain disruptions can reduce a company's revenues, cut into its market share, inflate its costs, send it over budget, and threaten production and distribution (Bosman, 2006). Neglecting issues relating to supply chain management, especially quality and cost, are particularly damaging to businesses operating in competitive environments, as QSRs are (Slone, 2007).

The QSR managers identified a range of economic factors, including currency exchange rates, inflation and competition, many of which were vital for businesses in any business context. They also mentioned the global economic crisis of 2009, which had a major impact on customers' income and was reflected in their purchasing power. Various authors have commented on the importance of economic factors. Parsa (2011) stressed the importance of economic factors in the survival and success of restaurants. Katsikeas et al. (2006) highlighted the importance of the economic situation in host countries on supply and demand in the QSR market. In the same vein, Kotler and Armstrong (2010) commented that the economic situation affects the purchasing power of customers. Furthermore, Clarke and Chen; 2007; Morgan; 2011 pointed out the importance of economic factors in relation to the operating costs for a business and disposable income for customers.

There are some challenges which facing global brand (out home borders) such as local cultures and language differences, government regulations, politics issues, (Gregory and Wiechmann, 2011). Furthermore, from the political issues what happened with "McDonald's QSRs in Belgrade which came under attacks in protest against the NATO air strikes in early 1999" (Ball, 2000:163).

Figure 3: Challenges that faces global brands

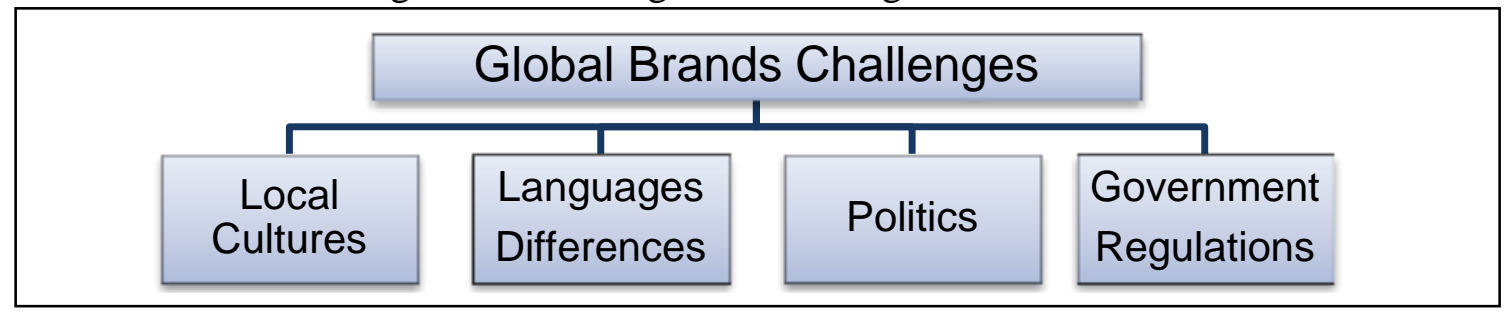

Source: (Gregory and Wiechmann, 2011)

\section{Methodology}

Crotty (1998: 3) defines methodology as "the strategy, plan of action, process or design lying behind the choice and use of particular methods and linking the choice and use of methods to the desired outcomes". The research methodology adopted in this study is case study. A case study is an effective tool for an exploratory research and is often used to explore 'how' and 'why' questions (Yin, 2009). Cresswell (2009) suggested that when there is limited information about a phenomenon at the start of a 
research study, as there was with this study, the research merits a qualitative approach.

Figure 4: Qualitative research elements

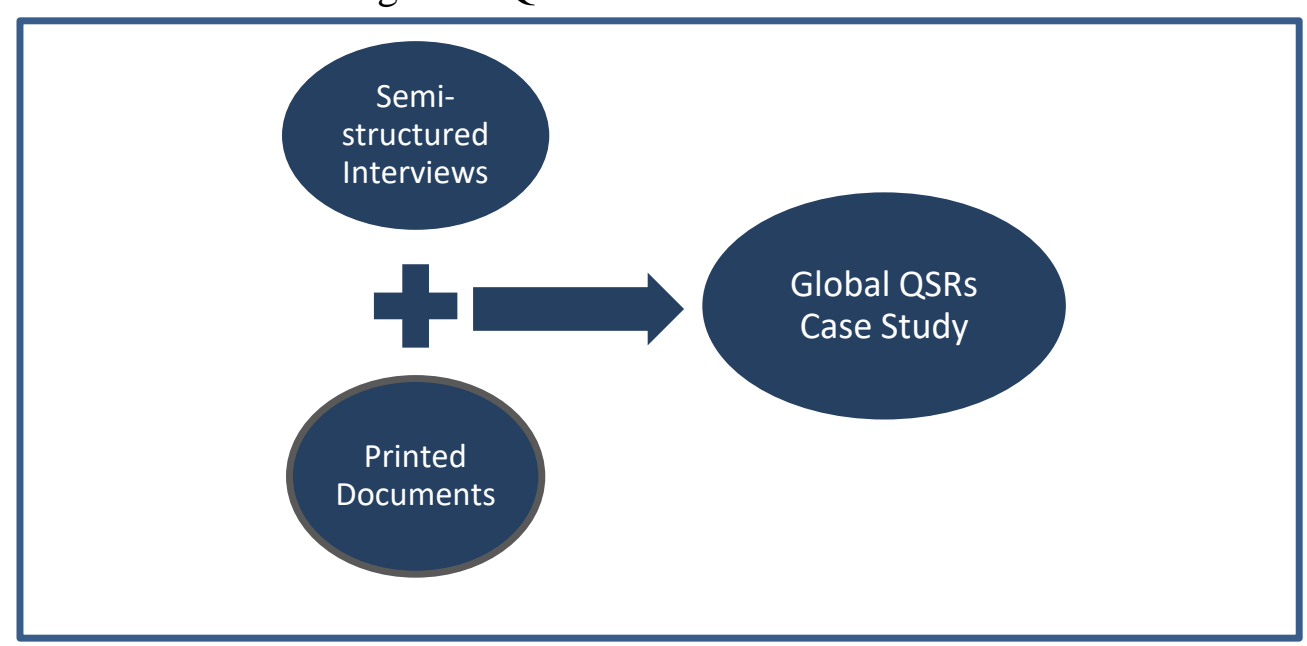

The results identified various challenges facing global QSRs of recognizably American-origin, such as McDonald's Egypt, operating in highly competitive marketplaces in Egypt. These included economic challenges (inflation, currency exchange rates and the global economic crisis), health challenges (mad cow disease, avian flu and swine flu). All the data presented in this chapter was collected in 40 semi-structured interviews with operational, marketing and branch managers of global QSRs and industrial practitioners and experts in Egypt in June 2009 until 2013. The interviews were designed to draw on the perceptions and experiences of the economic challenges, which affect the operation of global chain QSRs. The global chain QSRs participating in the study were McDonald's, Hardee's, Kentucky Fried Chicken (KFC) and Burger King QSRs.

Figure 5: Three phases of collecting data

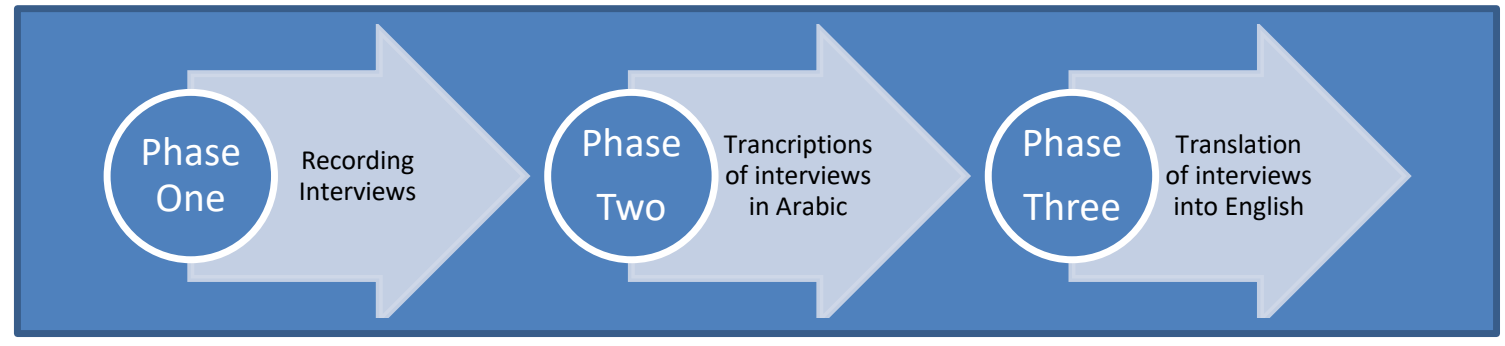

Table 1: Transcription and translation of the interviews

\begin{tabular}{|l|c|}
\hline Respondents & Position \\
\hline IN.EX.1 & Industry Expert \\
\hline GC-QSRM1 & General manager \\
\hline GC-QSRM2 & Assist. Manager \\
\hline GC-QSRM3 & Training manager \\
\hline GC-QSRM4 & McD Branch manager \\
\hline GC-QSRM7 & Supply chain manger \\
\hline GC-QSRM8 & KFC manager \\
\hline GC-QSRM10 & Burger King branch manager \\
\hline GC-QSRB5 & KFC supply chain Manager \\
\hline GC-QSRK6 & KFC Branch Manager \\
\hline GC-QSRK7 & Burger king supply chain manager \\
\hline GC-QSRK9
\end{tabular}




\section{Results and discussions}

One of (GC-QSRM7) commented that"a strong economy in the host country encourages global businesses and their new products to flourish" which agrees with the comments of Clarke and Chen (2007) who stated: "Economic factors, such as level of income, difference in income distribution and the extent and conditions of infrastructure, price reducing variation, are affected by fluctuations in the economy". Similarly, IN.EX.1 emphasized: "Economic factors play a vital role to attract investors so if the country has a positive economic situation it will attract foreign investors like global QSRs".

\section{- Raw material sourcing}

There are several economic problems in Egypt which have an effective impact on raw material costs, notably currency exchange rates and customs duties. Currency exchange rates play an important role in the importing of raw materials to nonWestern countries, as the McDonald's assistant general manager (Dziadosz, 2009) explained: "There are the main two factors: currency exchange rates and customs duties. In Egypt customs duties are high compared to the US and Europe".

To overcome issues related with currency exchange rates and customs duties McDonald's Egypt had implemented localization program which help reduce the volume of imported raw materials. On discussing, the sourcing of raw materials with the GC-QSRM1 explained:

There are two approaches to sourcing raw materials, the first one is localization strategy that we follow in Egypt and the second is an importation strategy. When we launched McDonald's Egypt in 1994 we imported raw materials from original sources while we worked on a localization strategy to manufacture and supply McDonald's restaurants across Egypt.

GC-QSRM8 explained that localization programs "aim to source more than $85 \%$ of raw materials" to McDonald's exacting quality standards. Similarly, one of the GCQSRM7 added: "We import meat from US, Australia and Mexico which is then processed by the Faragilo Company. McDonald's considers its raw material costs very carefully to ensure it makes a good profit".

Managing the supply chain includes planning for the sourcing of raw materials and coordinating with suppliers domestically and internationally. McDonald's Egypt faced considerable challenges in finding local suppliers who can deliver raw materials to meet their exacting specifications and quality measures. According to the GCQSRM1, the McDonald's localisation programme had achieved $85 \%$ of raw materials being locally manufactured, with just $15 \%$ (mainly meat and fish) being imported. McDonald's Egypt sources its burger patties from domestic suppliers, such as the Faragilo Company (a successful Egyptian food company processing frozen and canned vegetables, tomato paste, cheese and soups). It also is supplied by Farm Frits (a company that produces a range of potato products for the food service market). Cheese and vegetables were supplied by local Egyptian farms. McDonald's Egypt provided local suppliers with specifications for the food ingredients it required. Quality is critical and is continually monitored as the GC-QSRM1 explained: "there is a third partner between the sourcing company and the global QSRs - the auditing company - which is responsible for judging raw material quality before shipment to global QSRs". 
On the other side, one of the KFC manager explained that "Every product comes from our factory is ready to be served so there is minimum preparation in the QSR branch. Every product is frozen and is ready to fry or grill".

These results are consistent with those of Bosman (2006) and Slone (2007) who highlighted the importance of supply chain management in providing consistent raw material quality at a fixed price. High raw material costs negatively impact on global products, as emphasized by one of the GC-QSRM7: "High raw material costs decrease global QSR profits". Slone (2007) stressed the importance of food cost for competitive advantage in the QSR market.

\section{- Currency exchange rates}

Even importing $15 \%$ of its raw materials results in significant issues relating to currency exchange rates which McDonald's Egypt has had to address through currency hedging, i.e. it buys one million dollars of foreign exchange at a stable price to avoid risk associated with an increasing dollar rate against the Egyptian pound. GC-QSRK9 explained: "McDonald's QSRs implemented hedging programmes for six months through a non-profit company to get a stable price for commodities like meat and oil over a period of time to enable it to continue to offer its £5 LE menu". Most global chain QSRs operating in non-Western countries have had to adopt strategies to stabilize currency exchange rates in relation to raw material imports (Allayannis \& Miller, 2003).

\section{- Inflation}

Inflation in raw material prices had impacted negatively on both global and local chain QSR menu prices. According to (GC-QSRB5) "increases in raw material prices led to increases in food costs and sandwich packaging which impacted on sales". Bosman (2006) similarly noted the impact of inflation on sales in global chain QSRs. GC-QSRM1 explained: "the main problem is that the stock market traders in the Egyptian market are not sufficiently aware of the cash cycle".

Throughout 2008 and 2007, mainly 2008, we witnessed tremendous inflation in raw product prices. This was a worldwide thing, due to the inflation that occurred for all commodities. In some products, it went up to 40-45 percent. The majority of the locally-produced products depend on imported raw materials. So if you have any change in the worldwide low product pricing, definitely it will impact you. After all the inflation we have seen in 2008 , this might be a challenge we are faced with again in 2009. If the dollar gets stronger against the Egyptian pound and the Egyptian pound is devalued, what worries me is seeing inflation again in the Egyptian market. So the majority of the inflation affected us internally on our profitability, and we just passed a minor part onto the consumer. One of the main products was beef. To give you an example, beef prices - this is an estimated number went from around, let's say, $\$ 2,800$ per ton to $\$ 4,500$ per ton. So imagine what happened to the raw material costs. We didn't transfer all of this, definitely, but it did affect our profitability. (Dziadosz, 2009: online)

There are two kinds of inflation: the first is local inflation in the price of local raw materials; the second is global inflation which increases and decreases according to supply and demand globally. McDonald's strategy to overcome high inflation involved changing raw material sources, as the GC-QSRM8 explained: “... changing 
the raw material source, like purchasing meat from Australia, UK, Europe, Brazil, and South Africa, instead of the US. Sourcing raw materials from these countries depends on the currency of sourcing country".

According to McDonald's assistant general manager (Dziadosz, 2009: online) there are particular strategies to overcome the hurdle of high inflation in raw material prices in order to maintain a competitive position:

One of our strategies is that we don't dump all of the inflation on the consumer, because we have to maintain our competitiveness, especially in regards to pricing. We share inflation with customers. To avoid products' prices to go out of range, the inflation will be shared with the customer i.e. one half of the inflation will be put on the product and the other half will be covered by the company. All to maintain company position in the Egyptian market.

Similarly, the GC-QSRM8 elaborated:

We are doing business with suppliers in the following principles: no bargaining; technical support; we develop suppliers through a longterm vision; we do not sign contracts, we have very strong relationship and partnerships with suppliers which consider consistent quality to achieve the standardized product.

McDonald's Egypt negotiated agreements with suppliers to supply large quantities of high quality products at relatively small profit margins. As the GC-QSRM8 explained: "It was all to avoid harming our brand name as well as losing the trust of our suppliers". The GC-QSRM8 explained: “... in hard times - for example when there is high inflation - suppliers will support you by supplying large quantities of raw materials at agreed quality standards with small profit margins". Such partnership arrangements help to maintain competitiveness. The GC-QSRM1 explained: "We revised our pricing protocols with suppliers" to put pressure on suppliers to get raw materials at lower prices. Moreover, the GC-QSRM8 emphasised: "We cannot put pressure on suppliers to get a lower price which negatively impacts on the quality standards as this would jeopardise our brand name and image". The IN.EX.1 elaborated that in the recession: "McDonald's did not make any workers' redundant but put pressure on suppliers to get lower prices".

\section{- The global recession}

The global economic crisis of 2009 had a major negative impact on the purchasing power of the Egyptian customers and resulted in a significant drop in money on purchasing QSR products. As many McDonald's Egypt customers worked in the field of banking and tourism, they experienced reduced disposable income which resulted in a slump in QSR sales. As the GC-QSRK9 explained: "The global economic crisis affected our customers' incomes and was reflected in their disposal incomes for eating out" as Parsa (2000) highlighted on the importance of families' disposal income for restaurant expenditure.

Three of the interviewees (GC-QSRM2, GC-QSRM4 and GC-QSRM7) pointed out that the global economic crisis had affected all economic sectors, but had particularly badly affected employees in the banking and tourism sectors who were their major customers. One of the GC-QSRM7 explained: "Inflation caused the global economic downturn which has led to a rise in raw material costs, increased prices and a decrease in restaurant profits".

Most Egyptian customers like to feel they are getting value for money, particularly in challenging economic circumstances as the GC-QSRK9 explained: "Recession in the 
market has required a difficult homework exercise in designing new products at suitable prices by getting supplies at low prices but with good quality". Global QSRs have tried to recover their losses by launching special meals at suitable prices to attract customers and to overcome the recession by putting pressure on suppliers to get raw material at lower prices.

Some global QSR managers suggested conducting a market survey to study the current customers' purchasing power and other obstacles. For them, this step would help them understand sales patterns and to find new ways to enhance sales at reasonable prices. GC-QSRM2 considered market research an important tool in relation to the economic recession: "Market research gives information about your target customer and how much customer able to pay money in meal. Your strategy must be to go with the new trends in your market". By targeting specific customers, such as school and university students and factory workers through special offers is one way that QSRs have addressed issues relating to purchasing ability: "The global QSRs made offers for schools, universities and also for customers' birthdays to increase sales during the recession" (GC-QSRM7). One of the global QSR branch managers (GC-QSRH7) emphasised that in difficult economic situations: "Customers' incomes must be considered so that we can make a price adaptation". Kotler and Armstrong (2010) emphasised the importance of marketers paying close attention to major trends and consumer spending patterns.

GC-QSRK6 elaborated: "the Egyptian market is changeable so it is difficult to fix prices but there are local QSRs like Mo'men which focus on value for money and sandwich size". The GC-QSRM1 explained: "decreasing product prices gives branded affordability, the $5 \mathrm{LE}$ menus which we offered suited D and E class customers' incomes". The GC-QSRM3 added: "In spite of inflation McDonald's Egypt likes using the 5 LE menus, so we did not change our policies. The 5 LE menu means brand affordability. McDonald's global QSRs decreased its core menu prices for the Big Mac and McChicken sandwiches from 18.18 LE to 15.91 LE”. Morgan (2011) identified the relationship between product quantity and the price which customers are willing to pay for it.

The GC-QSRK9 explained: "KFC launched new meals called economic meals to send a message to our customers that we aim to save them money". In similar vein, GCQSRM4 explained: "McDonald's launched 5 LE menu to attract socio-economic class D customers". GC-QSRM3 explained: "The flourishing of the Egyptian economy will lead to increased customer incomes and increased budgets for eating out and will increase sales in QSRs".

\section{- Global food crises}

A range of challenges associated with global food crises have been faced by QSRs in Egypt, including mad cow disease (Bovine Spongiform Encephalopathy (BSE) - a deadly brain disease affecting a cow's nervous system causing it to act oddly), avian (bird) flu (a highly-infectious disease which can be passed from birds to humans), swine flu (H1N1) (an infectious disease originating from pigs which also can be passed to humans). These problems have had negative impacts on QSR sales and have challenged the viability of QSR operations which have struggled to maintain income to cover expenses associated with rents, electricity, water, restaurant maintenance and staff salaries. As a result of mad cow disease, McDonald's lost sales in its overseas markets:

McDonald's is often a scapegoat for the problems of fast feeders. It is true that the mad cow disease scares in Europe and falling foreign 
currencies have cut into McDonald's overseas sales which account for over half of total volume. Its stock dipped from $\$ 40$ per share in April 2000 to 25 \$ in April 2001 (Bernstein, 2001: 8).

McDonald's, Wendy's, CKE, and other large quick-serves issued press releases saying none of their beef came from supplies involving the BSE case. Even with a short trading day on the 24th, McDonald's stock fell more than 5 percent (Mad Cow Found in Washington State, 2003:1).

The vast majority of QSR products are made from beef and chicken and since many customers were afraid to eat beef and chicken products because of mad cow disease and avian flu as one of GC-QSRM6 explained: "Mad cow disease caused sales recessions in QSRs. Our core business concept is burger (beef) so customers were concerned that we made burgers from cows which had caught mad cow disease."

The GC-QSRM2 and GC-QSRM7 agreed that avian and swine flu affected customer purchasing intentions and caused a recession in the global QSRs. Avian flu impacted badly on the sale of chicken products in global QSRs as a result of customers' concerns that they would catch the virus if they ate chicken sandwiches.

During the swine flu epidemic McDonald's Egypt lost approximately 30-40\% from total sales as explained by GC-QSRM3: "McDonald's QSRs lost 30\%-40\% of total sales because of swine flu". To respond to the swine flu problem McDonald's worked at raising customer awareness about the $\mathrm{H} 1 \mathrm{~N} 1$ virus through support of governmental television advertising campaigns:

McDonald's Egypt played a major role in raising awareness of how to avoid the spread of swine flu (H1N1) virus, there is no doubt that lack of sufficient awareness had led to panic and fear, and as an Egyptian organization we contributed to alleviating this issue by cooperating with government efforts in providing awareness on the reality of the virus. We have started by educating employees, who in turn educated their families (GC-QSRM2 cited Dziadosz, 2009: online).

One of the GC-QSRM7 commented: "From the first time of global QSR television advertisements are designed to send a clear message to customers that our sandwiches are made from $100 \%$ pure beef meat so they know that we produce high quality products. From when we opened in 1994, we advertise our burgers as $100 \%$ pure meat. We take our meat from our local farms in Egypt".

Several global QSRs chain branch managers felt that the Egyptian Ministry of Health should announce in its advertisements that the H1N1 virus was not associated with global and local QSRs, as suggested for example by the GC-QSRM3 explained that: "Ministry of Health should mention that there is no swine flu in these global QSRs products." On the other side, GC-QSRM7 criticized McDonald's product variety QSRs said that: "McDonald's focuses on meat products. If there are any problems relating to eating meat products - like mad cow and swine flu diseases - McDonald's is very vulnerable". The GC-QSRM8 explained:

The swine flu crisis is not well-organized because the Egyptian government slaughtered all the pigs in Cairo at the same time. Egyptians had concerns that all meat products in the market or in the global QSRs at that time might contain pork and so meat product sales decreased by $40 \%$.

These global food crises impacted badly on global QSRs in Egypt. The crises were managed in different ways, for example the source country was changed, new products (e.g. the McFalafel) were launched, television advertisements and other 
promotional materials were developed that drew on brand trust, and training programs related to personal hygiene, specifically the use of hand sanitizers were delivered. GC-QSRM8) elaborated: "Imported burger patties come from America which is not a host country for mad-cow disease". The introduction of a wide ingredient base (beef, poultry and fish) to a QSR menu helps overcome global food crises as observed by GC-QSRM5: "A QSR can face big problems in relation to loss of sales if it just serves one item which can be overcome by serving a variety of products - meat, chicken and seafood"

Figure 6: The economic challenges and proposed solutions in Egypt

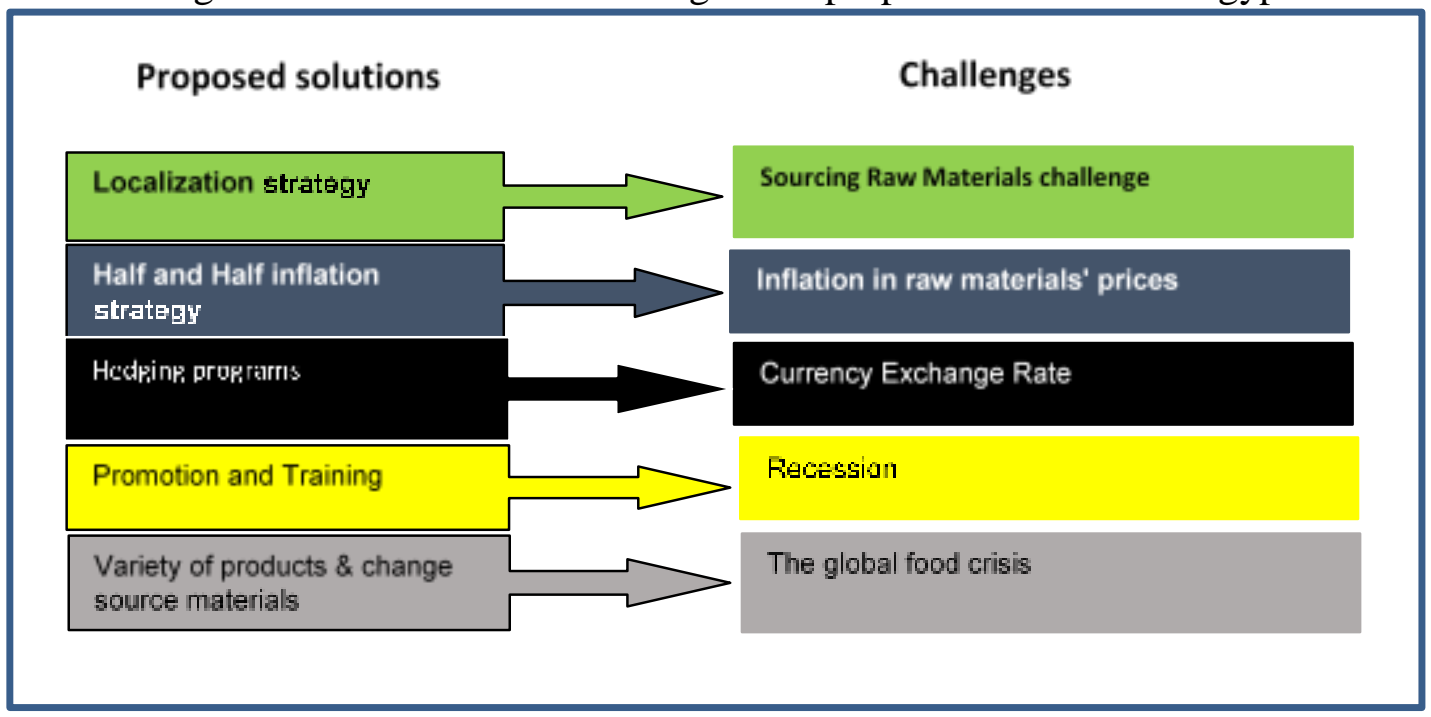

\section{Findings and recommendations}

The findings are highlight the importance of a rich understanding of challenges which facing the global QSRs in Middle East countries. The research concludes that several strategies to overcome on the challenges facing the global QSRs particularly American-branded QSR franchises, such as McDonald's, in highly competitive the non-Western marketplaces. So, this study recommended that:

- It is not a difficult homework exercise to understand local supply and demand in the Egyptian market.

- The global QSRs should adopt localization strategy in the Egyptian market.

- The Egyptian governments should encourage global QSRs to produce its entire product globally.

- The global QSRs should serve a wide range of products to maintain its profit during local and global crises.

- The global QSRs should launch an economic meals and sandwiches during recession periods.

- The global QSRs should scale back their investment in training and development through recession periods.

- The global QSRs should avoid pressure on the suppliers to prevent jeopardizing its brand name.

- The global QSRs should not dump all of the inflation on the consumer. 


\section{References}

Allayannis, G. Lel U. \& Miller D. P. 2003. Corporate Governance and the Hedging Premium Around the World.

Apte, U. M. \& Reynolds, C. C. 1995. Quality management at Kentucky Fried Chicken. Interfaces, (25)3, 6-21.

Ball, S. \& Roberts, L. 2003. Restaurants. In: B. Brother (Ed.). The international hospitality industry; structure, characteristics and issues. Oxford. Butterworth-Heinemann.

Ball, S. 2000. Catering. In: C. Lashley \& A. Morrison (Eds.). Franchising hospitality services. Oxford. Butterworth-Heinemann.

Bernstein, C. 2001. Defending the arches. Editor-At-Large.

Bosman, R. 2006. The new supply chain challenge: risk management in a global economy. Johnston, RI: FM Global, Factory Mutual Insurance Company: 1-12.

Bosman, R. 2006. The new supply chain challenge: risk management in a global economy. Windsor. FM Global, Factory Mutual Insurance Company.

Brown, A. \& Weiner, E. 1984. Supermanaging: How to harness change for personal and organizational success. New York: McGraw Hill.

Christopher, M., 2016. Logistics \& supply Chain Management. Pearson. UK.

Clarke A. and Chen W. (2007)."International Hospitality Management: Concepts and Cases." Butterworth-Heinemann. pp. 77.

Creswell, J. W. 2009. Research design: qualitative, quantitative, and mixed methods approaches $\left(3^{\text {rd }}\right.$ ed.). Los Angeles; London. Sage Publications.

Crotty, M. 1998. The foundations of social research: meaning and perspective in the research process. London. Sage Publications.

Dziadosz, A. 2009. Interview: McDonald's Alaa Fathy on making fast food in Egypt. Dailynews. Available from: http://www.thedailynewsegypt.com/interviewmcdonalds-alaa-fathy-on-making-fast-food-in-egypt.html. [Accessed on: 01/04/2009].

Kara, A., Kaynak, E. \& Kucukemiroglu, O. 1997. Marketing strategies for fast-food restaurants: a customer view. International Journal of Contemporary Hospitality Management, 7(4), 16-22.

Katsikeas C. S., Samiee S., Theodosiou M. (2006). "Strategy Fit and Performance Consequences of International Marketing Standardization" Strategic Management Journal, John Wiley Sons Ltd. PP. 867.

Katsikeas, C. S., Samiee, S. \& Theodosiou, M. 2006. Strategy fit and performance consequences of international marketing standardization. Strategic Management Journal, 27(9), 867-890.

Kotler and Armstrong (2010). "Principles of Marketing" $13^{\text {th }}$ ed. Pearson Education, Pearson Prentice Hall, New Jersy. USA. PP. 103.

Kotler and Armstrong (2010). "Principles of Marketing" $13^{\text {th }}$ ed. Pearson Education, Pearson Prentice Hall, New Jersy. USA. PP. 103. Online)

Mad Cow Found in Washington State. 2003. QSR Magazine. Available from: http://www.qsrmagazine.com/articles/news/story.phtml?id=4175. [Accessed on: 5/07/2009]. Mad Cow Found in Washington State, 1

Morgan L. (2011) "Factors That Affect Supply \& Demand" http://www.ehow.com/info_8132502_factors-affect-supply-demand.html

Morgan, L. 2011. Factors that affect supply \& demand. Available from: http://www.ehow.com/info 8132502 factors-affect-supply-demand.html. [Accessed on: $11 / 09 / 2011]$.

Ottenbacher, M. C. \& Harrington, R. J. 2009. The product innovation process of quickservice restaurant chains. International Journal of Contemporary Hospitality Management, 21(5), 523-541.

Parsa, H., Self, J., Sydnor-Busso, S. \& Yoon, H. J. 2011. why restaurants fail? part ii-the impact of affiliation, location, and size on restaurant failures: results from a survival analysis. Journal of Foodservice Business Research, 14(4), 360-379. 
International Journal of Heritage, Tourism and Hospitality Vol. (11), No. (2/2), September, 2017 By: Faculty of Tourism and Hotels, Fayoum University

Parsa, H., Self, J., Sydnor-Busso, S., \& Yoon, H. J. 2011. Why Restaurants Fail? Part II-The Impact of Affiliation, Location, and Size on Restaurant Failures: Results from a Survival Analysis. Journal of Foodservice Business Research, 14(4): 360-379.

Vignali, C. 2001. McDonald's:"think global, act local"-the marketing mix. British Food Journal,103(2), 97-111. 